Limnol. Oceanogr., 46(8), 2001, 1990-1997

(C) 2001, by the American Society of Limnology and Oceanography, Inc.

\title{
Toxicity in Peridinium aciculiferum — an adaptive strategy to outcompete other winter phytoplankton?
}

Karin Rengefors ${ }^{1}$

Department of Limnology, Evolutionary Biology Centre, Uppsala University, Norbyvägen 20, SE-752 36 Uppsala, Sweden

\section{Catherine Legrand}

Marine Science Division, Department of Biology and Environmental Science, University of Kalmar, S-391 82 Kalmar, Sweden

\begin{abstract}
Freshwater dinoflagellates may form dense blooms during winter in ice-covered lakes. Unlike their marine counterparts, freshwater dinoflagellates are rarely considered to be potential toxin producers. Here we tested whether the winter species Peridinium aciculiferum produces a toxin(s) and investigated the potential adaptive function of that toxin, i.e., predator defense or inhibition of competitors (allelopathy). Using traditional toxicity bioassays (Artemia toxicity test and hemolytic activity assay), we detected the production of a toxic substance by $P$. aciculiferum cells from both the field and from laboratory cultures. Cultures deprived of phosphorus and in stationary phase showed highest toxicity. Potential predators, such as Daphnia galeata (Cladocera) and Eudiaptomus graciloides (Copepoda), were apparently not harmed by $P$. aciculiferum toxicity. However, the naturally cooccurring competitor Rhodomonas lacustris (Cryptophyceae) was killed by P. aciculiferum. An allelopathic substance(s) caused the cells of $R$. lacustris to form blisters and subsequently lyse. We concluded that our results support the hypothesis that $P$. aciculiferum is allelopathic, but not that toxins serve as predator defense. We therefore suggest that allelopathy may be an adaptive strategy of winter dinoflagellates, which could allow them to outcompete other phytoplankton species and thereby dominate the algal biomass.
\end{abstract}

Freshwater dinoflagellates are generally considered to be nontoxic and harmless algae despite the fact that their marine counterparts may be extremely toxic and can have substantial negative effects on the systems they occur in. In freshwater phytoplankton communities, dinoflagellates are a common component and may dominate the biomass completely during late summer in temperate lakes. In addition, dinoflagellates can also form extensive blooms under ice during late winter and early spring, a phenomenon that has received little scientific attention.

The adaptive function of toxin production in phytoplankton is still debated. Possible functions may be repulsion of grazers, inhibition of cooccurring phytoplankton species (allelopathy), release of degradation products, or storage of products (Turner and Tester 1997). Regardless of which evolutionary forces have led to toxin production in marine di-

${ }^{1}$ Present address: Limnology, Department of Ecology, Ecology Building, Lund University, SE-223 62 Lund, Sweden (Karin. Rengefors@limnol.lu.se).

\section{Acknowledgments}

We are grateful to P. Blomqvist for first suggesting that we should investigate Peridinium aciculiferum. We thank E. Nilsson for field and laboratory assistance. A. Qvarnström, S. Dyhrman, and two anonymous reviewers, provided helpful comments on the manuscript. T. Vrede kindly provided cultures of Daphnia and Rhodomonas and R. Bjerselius generously provided fish blood. The Swedish Environmental Protection Agency granted economic support for this study. Further financial support was provided by The Swedish Foundation for International Cooperation in Research and Higher Education (STINT), The Wallenberg Foundation, and the European Commissions Environment and Sustainable Development program (FP5, BIOHAB-EVK3-CT99-00015). noflagellates, freshwater species should be exposed to similar selective forces.

Among marine dinoflagellates, several are ichthyotoxic (Steidinger 1983; Burkholder et al. 1995), being lethal to larval, juvenile, and adult fish of several species (Turner et al. 1998). Ichthyotoxic dinoflagellates can either have a direct deleterious effect on fish or a vectorial one, i.e., intoxication through prey that have accumulated toxins through grazing, but are themselves immune to the toxin (Turner and Tester 1997). There are a few cases reporting toxic freshwater dinoflagellate blooms (Adachi 1965; Hashimoto et al. 1968; Jurgens 1953). The available evidence suggests that dinoflagellates within or related to the Peridinium genus are potential producers of toxins. Peridinium polonicum (now Peridiniopsis polonicum) caused fish kills in a reservoir in Japan (Adachi 1965). Another species, Peridinium bipes, was recently shown to have an algicidal effect on the cyanobacteria $\mathrm{Mi}$ crocystis aeruginosa (Wu et al. 1998). Mills et al. (1995) reported suspected fish kills due to algal toxins released by dinoflagellates in an artificially acidified lake. A potential candidate for ichthyotoxic dinoflagellates in lakes is Peridinium aciculiferum. This dinoflagellate is often found in large numbers in winter phytoplankton communities under ice in some Swedish lakes (Rengefors 1998). During a $P$. aciculiferum bloom, only other small dinoflagellate species cooccur at any significant biomass (Nauwerck 1963; Rengefors 1998).

It is possible that toxic blooms of dinoflagellates in freshwater occur more frequently than reported and that they affect the biota in those habitats. For example, the presence/ absence of $P$. aciculiferum may be coupled to the recruitment success of vendace (Coregonus albula) larvae in Lake Mälaren, Sweden. Circumstantial evidence suggests 
Table 1. Sampling sites for Peridinium aciculiferum in two Swedish Lakes in Feb-Mar 2000; Lake Mälaren (At Ekoln and Adelsö) and Lake Erken. Lake Edasjön was sampled for copepods only.

\begin{tabular}{|c|c|c|c|c|}
\hline Sampling site & Location & Date & $\begin{array}{c}\text { Ice cov- } \\
\text { er }\end{array}$ & Peridinium (cells $\mathrm{ml}^{-1}$ ) \\
\hline \multicolumn{5}{|l|}{ Lake Mälaren } \\
\hline \multirow[t]{3}{*}{ Ekoln } & $59^{\circ} 45^{\prime} \mathrm{N}, 17^{\circ} 36^{\prime} \mathrm{E}$ & $10 \mathrm{Feb}$ & Yes & 0 \\
\hline & & $24 \mathrm{Feb}$ & Yes & 0 \\
\hline & & 5 Mar & Yes & 0 \\
\hline \multirow[t]{4}{*}{ Adelsö } & $59^{\circ} 17^{\prime} \mathrm{N}, 17^{\circ} 31^{\prime} \mathrm{E}$ & $11 \mathrm{Feb}$ & Yes & 0 \\
\hline & & 22 Feb & Yes & 240 \\
\hline & & 8 Mar & Yes & 0 \\
\hline & & $20 \mathrm{Mar}$ & No & 0 \\
\hline \multirow[t]{4}{*}{ Lake Erken } & $59^{\circ} 51^{\prime} \mathrm{N}, 18^{\circ} 35^{\prime} \mathrm{E}$ & 3 Mar & Yes & 40,640 \\
\hline & & 7 Mar & Yes & 13,480 \\
\hline & & $10 \mathrm{Mar}$ & Yes & 13,840 \\
\hline & & $14 \mathrm{Mar}$ & Yes & 16,880 \\
\hline Lake Edasjön & $59^{\circ} 48^{\prime} \mathrm{N}, 17^{\circ} 54^{\prime} \mathrm{E}$ & $23 \mathrm{Mar}$ & Yes & \\
\hline
\end{tabular}

that poor recruitment occurs where $P$. aciculiferum is present (Nyberg et al. 1998). Vendace larvae hatch at the end of April concurrent with ice-out. Yolk-sac and first-feeding larvae of various marine fish species ingest dinoflagellates and herbivorous zooplankton (Turner and Tester 1997). Consequently, if larvae emerge simultaneously or following a bloom of dinoflagellates, the phycotoxins could be potentially devastating (Hjort 1914; Lasker 1971). Planktivorous fish are likely to eat dinoflagellates, since their fatty acid content makes them high quality food (Ahlgren et al. 1992). For example, in Lake Kinneret, Israel, the fish Tilapia galilaea selectively feeds on Peridinium cinctum (Spataru 1976). Alternatively, first-feeding larvae risk vectorial ingestion of phycotoxins through intake of copepods and rotifers that may have fed on dinoflagellates. Peridinium aciculiferum is within the size range of a potential food source for vendace larvae or as prey for zooplankton, which then provide a food source for the fish larvae. If $P$. aciculiferum produces ichthyotoxins, this may be the cause of death for fish larvae, resulting in the poor recruitment of vendace in Lake Mälaren during the past 10 yr (Nyberg et al. 1998).

Here we present the results of a study designed to determine (1) whether the freshwater dinoflagellate Peridinium aciculiferum produces toxin(s) and (2) whether the adaptive function of the toxin(s) is to inhibit competitors or whether it is a defense against grazers. Our strategy was to use traditional toxicity tests to detect any toxin and then to test for acute negative effects of $P$. aciculiferum cells and cell-free filtrate on zooplankton (predators) and phytoplankton (competitors).

\section{Methods}

Sampling sites-Dinoflagellates were sampled during the winter of 2000 in two Swedish lakes, Lake Mälaren (Ekoln and Adelsö sites) and Lake Erken (Table 1). Ekoln, a eutrophic bay, has good recruitment of Coregonus albula (vendace), while Adelsö, located in the central less eutrophic part of the lake, does not. Lake Erken is known to have Peridi- nium aciculiferum blooms during late winter/early spring but is not populated with Coregonus albula.

At all sites, 10-20 liters of water were collected at 0-2 $\mathrm{m}$ depth below the ice. A subsample of $50 \mathrm{ml}$ was taken out and preserved for phytoplankton counts with Lugol's solution. Ten liters were concentrated through a $20-\mu \mathrm{m}$ sieve. The sieved and the unsieved fraction were filtered onto a GF/C filter in the laboratory. The filters were frozen and stored at $-20^{\circ} \mathrm{C}$. On one occasion (14 March 2000), cells from Lake Erken were collected, processed, and analyzed immediately.

Phytoplankton and zooplankton cultures-A strain of Peridinium aciculiferum, isolated from Lake Erken, was used for all the experiments. This culture has been identified as $P$. aciculiferum Lemmermann according to Popovsky and Pfiester (1990) by analyzing plate patterns through SEM (Fig. 1) in collaboration with B. Meyer (see also Rengefors 1998). Exponentially growing cells of $P$. aciculiferum were harvested from cultures grown at $3^{\circ} \mathrm{C}$ using diatom medium (DM) (Beakes et al. 1988). Cells of $P$. aciculiferum were also harvested during stationary phase in cultures grown at $2^{\circ} \mathrm{C}$, in phosphate replete medium $(\sim 90 \mu \mathrm{M})$, and in phosphate poor medium $(\sim 2 \mu \mathrm{M})$. Phosphorus (P) limitation was confirmed by decreased $\mathrm{P}$ content and increased $\mathrm{C}: \mathrm{N}: \mathrm{P}$ ratios based on CHN and particulate phosphorus analysis respectively (Table 2). Aliquots of cultures were filtered onto $\mathrm{GF} / \mathrm{C}$ filters, amounting to $1.6 \times 10^{6}$ cells of P-replete cells, and $0.8 \times 10^{6} \mathrm{P}$-deficient cells per filter. The filters were placed in cryovials and stored at $-70^{\circ} \mathrm{C}$. For long-term preservation the filters were freeze-dried for $5 \mathrm{~h}$ and subsequently stored at room temperature.

The other organisms used in this study are listed below. Rhodomonas lacustris Pascher and Ruttner isolated from Lake Erken was grown at $17^{\circ} \mathrm{C}$ in L16 medium (Lindström 1991). Prior to the allelopathic tests, $R$. lacustris cultures were transferred to the same conditions as $P$. aciculiferum cultures. Daphnia galeata Sars isolated from Lake Erken 1992 was cultured in the laboratory and fed with Rhodo- 

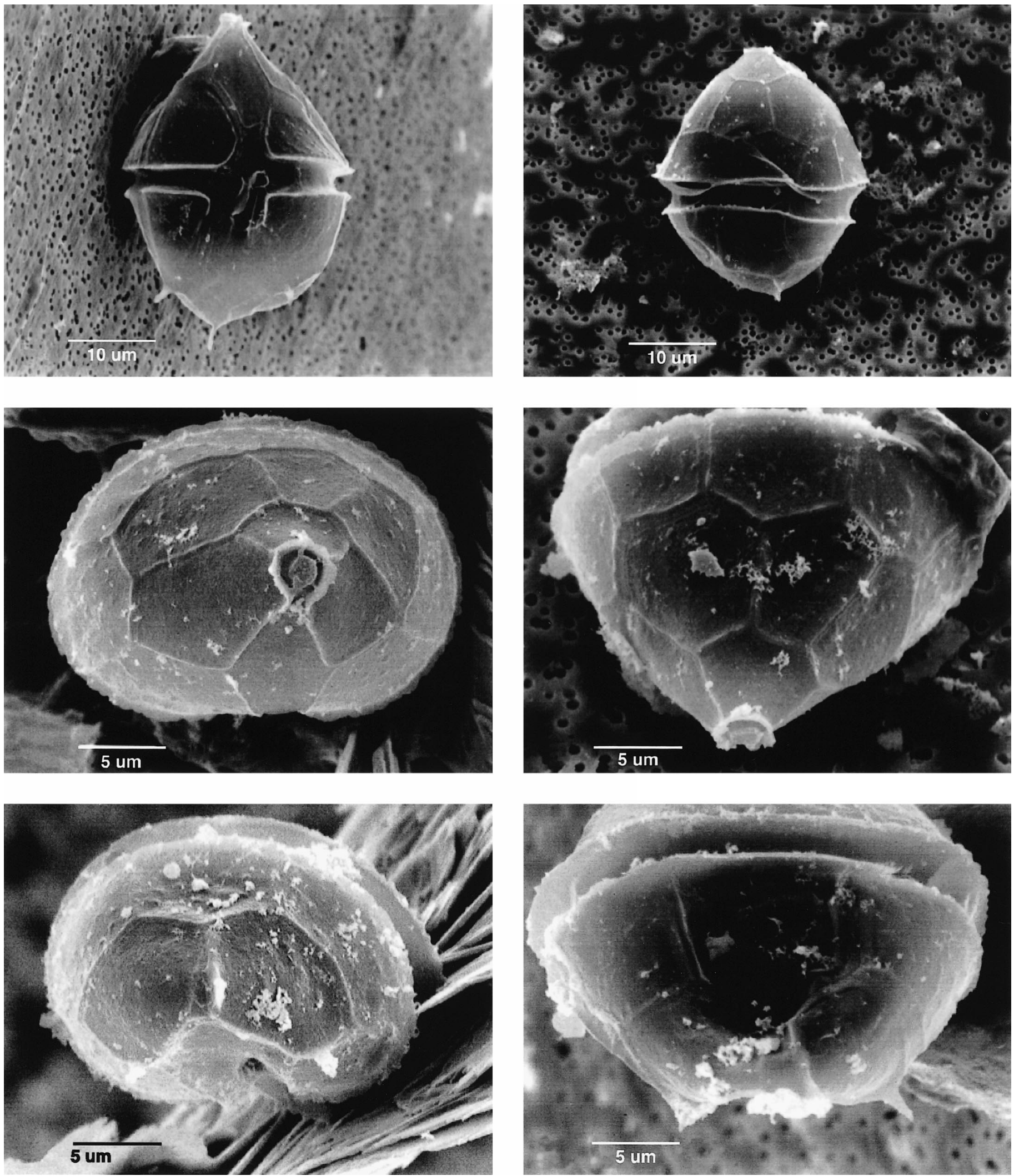

Fig. 1. SEM micrographs of Peridinium aciculiferum Lemmermann showing the tabulation pattern allowing for identification. The cell is shown in ventral and dorsal views, of the whole cell in the top row, the epitheca in the second row, and hypotheca in the bottom row. 
Table 2. Phosphorus, nitrogen, carbon content per cell, and $\mathrm{C}$ : $\mathrm{N}: \mathrm{P}$ (molar) ratio of P-limited and P-replete stationary phase cultures of Peridinium aciculiferum. Mean $\pm \mathrm{SD}, n=5$. Note that the $\mathrm{C}: \mathrm{N}: \mathrm{P}$ ratio for the average nutrient replete algal cell is considered to be $105: 16: 1$.

\begin{tabular}{lcccc}
\hline \hline & $\begin{array}{c}\text { Carbon } \\
\text { content } \\
\left(\text { ng cell }^{-1}\right)\end{array}$ & $\begin{array}{c}\text { Nitrogen } \\
\text { content } \\
\left(\text { ng cell }^{-1}\right)\end{array}$ & $\begin{array}{c}\text { Phosphorus } \\
\text { content } \\
\left(\text { pg cell }^{-1}\right)\end{array}$ & C : N : P \\
\hline Preatment & $2.0 \pm 0.52$ & $0.17 \pm 0.030$ & $87 \pm 14$ & $62: 4: 1$ \\
P-limited & $2.1 \pm 0.33$ & $0.2 \pm 0.057$ & $30 \pm 6.7$ & $176: 15: 1$ \\
\hline
\end{tabular}

monas lacustris. Copepods (mostly Eudiaptomus graciloides Liljeborg) were collected in Lake Edasjön with a 100- $\mu \mathrm{m}$ net tow under a $50-\mathrm{cm}$ ice cover. Live copepods were concentrated and kept for $24 \mathrm{~h}$ in the dark at $2-3^{\circ} \mathrm{C}$ prior to toxicity tests. Eggs of Artemia salina were hatched according to Vanhaecke et al. (1981) using deionized water with a salinity of 5\%o and $\mathrm{pH} 8.0$. The tolerance of A. salina to the different filtrates (lysed cells) or live cells of $P$. aciculiferum was examined on nauplii $48 \mathrm{~h}$ after hatching began.

Hemolytic activity - Stationary phase cells retained on filters were extracted with methanol $(100 \%)$, sonicated $(10 \times$ $10 \mathrm{~s}$ pulses), and filtered through a $0.2-\mu \mathrm{m}$ filter. Exponential phase cells and lake water samples were concentrated by centrifugation $\left(3,000 \mathrm{~g}\right.$ at $\left.4^{\circ} \mathrm{C}, 15 \mathrm{~min}\right)$. After centrifugation the pellet was transferred to a $1.5 \mathrm{ml}$ microfuge tube and extracted with methanol $(200 \mu \mathrm{l}$ to an original of $50 \mathrm{ml}$ culture). The final extracts (filtrates) were stored at $-20^{\circ} \mathrm{C}$ prior to analysis of hemolytic activity (HA). The HA test was performed as reported in Johansson (2000). The test was done in triplicate, and methanol was used as an optical blank. The HA of the cells was determined as saponin equivalents per cell $\left(\mathrm{SnEq}\right.$ cell $\left.^{-1}\right)$. Hemolytic activity was also measured using fresh fish blood from rainbow trout in order to test toxicity against an organism that occurs in lakes. The same protocol was followed as for horse blood, except that fish blood was treated with heparin to prevent coagulation. The test was performed on stationary phase cultured cells only.

Artemia salina bioassay-Cells of exponential phase $P$. aciculiferum from P-deplete and -replete cultures were concentrated $(10 \mathrm{~min}$ at $3,000 \mathrm{~g})$ and then diluted to give a concentration series of P-deplete $\left(360,1,600\right.$ cells ml $\left.^{-1}\right)$ and P-replete $\left(3,200\right.$ cells $\left.\mathrm{ml}^{-1}\right)$ cultures. Stationary phase cells of $P$. aciculiferum on freeze-dried filters $(\mathrm{GF} / \mathrm{C})$ were resuspended in DM medium (at $\mathrm{pH} 10$ ) and sonicated (10 pulse $\times 10 \mathrm{~s}$ ). The liquid phase (lysed cells) was filtered through $0.2-\mu \mathrm{m}$ filters (polyethersulfone). Filtrates obtained after the lysis and filtration of P-deplete cells corresponded to an addition of 36,000 cells $\mathrm{ml}^{-1}$. Control tests were performed to rule out any effect of $\mathrm{pH}$, salinity, or filters. The toxicity of a natural phytoplankton sample from Lake Erken (14 March 2000) containing $P$. aciculiferum was tested using the whole water sample $\left(20\right.$ cells $\left.\mathrm{ml}^{-1}\right)$ and the fraction $>20 \mu \mathrm{m}(1,000$ Peridinium cells $\left.\mathrm{ml}^{-1}\right)$.

Microwells (Falcon multiwell, 12 wells) were filled with $2 \mathrm{ml}$ of $P$. aciculiferum culture, lysate with medium, or me-
Table 3. Haemolytic activity of Peridinium aciculiferum cells in Lake Erken samples and cultures at different growth stages. Haemolytic activity was measured with horse and/or fish blood. Mean $\pm \mathrm{SD}, n=3$.

\begin{tabular}{|c|c|c|}
\hline \multirow[b]{2}{*}{ Sample } & \multicolumn{2}{|c|}{ Haemolytic activity $\left(\mathrm{SnEq}\right.$ cell $\left.{ }^{-1}\right)$} \\
\hline & Horse blood & Fish blood \\
\hline \multicolumn{3}{|l|}{ Lake Erken } \\
\hline $\begin{array}{r}3 \text { Mar } 2000 \\
14 \text { Mar } 2000\end{array}$ & $\begin{array}{l}2.87 \pm 0.14 \\
\text { not detected }\end{array}$ & $\begin{array}{l}\text { not measured } \\
\text { not measured }\end{array}$ \\
\hline \multicolumn{3}{|l|}{ Cultures } \\
\hline $\begin{array}{l}(-\mathrm{P}) \text { stationary } \\
(+\mathrm{P}) \text { stationary } \\
(-\mathrm{P}) \text { exponential } \\
(+\mathrm{P}) \text { exponential }\end{array}$ & $\begin{array}{l}1.61 \pm 0.32 \\
1.11 \pm 0.1 \\
\text { not detected } \\
\text { not detected }\end{array}$ & $\begin{array}{c}2.38 \pm 0.19 \\
0.92 \pm 0.11 \\
\text { not measured } \\
\text { not measured }\end{array}$ \\
\hline
\end{tabular}

dium only. There were five replicates for each treatment. Twenty-five Artemia nauplii were then added to each microwell. After 24 and/or $48 \mathrm{~h}$ incubation at $3^{\circ} \mathrm{C}$, the mortality of nauplii at each concentration was examined. Nauplii were observed under a dissecting scope and were counted as dead if no movement was observed within $10 \mathrm{~s}$.

Toxic effect on predators-Acute toxicity of P-replete and P-deplete $P$. aciculiferum cultures ( 400 cells $\mathrm{ml}^{-1}$ ) and Lake Erken concentrate containing $P$. aciculiferum (14 March 2000, 1000 cells $\mathrm{ml}^{-1}$ ) were tested on Daphnia cultures. Two-milliliter samples of $P$. aciculiferum were added to 2$\mathrm{ml}$ wells (Falcon, multiwell, 12 wells). As controls, DM medium without cells was used. Three to four Daphnia were transferred to each well with five replicates for each treatment and were incubated at $3^{\circ} \mathrm{C}$ for 24 and/or $48 \mathrm{~h}$. The control samples were incubated at $3^{\circ} \mathrm{C}$ and $15^{\circ} \mathrm{C}$ to eliminate a possible effect of temperature on $D$. galeata survival. The numbers of live and dead Daphnia were counted under a dissecting scope. Daphnia that did not move in $10 \mathrm{~s}$ were considered dead.

Acute toxicity of P-deplete cultures of P. aciculiferum was also tested on a natural assemblage of calanoid copepods

Table 4. Mortality of Artemia salina incubated for $24 \mathrm{~h}$ with live Peridinium aciculiferum cells or cell-free lysate, and in controls (medium only). Mortality shown as percentage, with mean \pm SD. The field sample was not tested statistically, but note the difference in mortality between control and treatment. Lake Erken, 14 Mar 2000 .

\begin{tabular}{lccc}
\hline \hline & & \multicolumn{2}{c}{$\begin{array}{c}\text { Mortality of Artemia } \\
\text { salina }(\%)\end{array}$} \\
& $\begin{array}{c}\text { Cell conc. } \\
\text { after } 24 \mathrm{~h} \text { exposure }\end{array}$ \\
\cline { 2 - 4 } Peridinium treatment & $\begin{array}{c}\left.\text { cells } \mathrm{ml}^{-1}\right) \\
\text { liferum }\end{array}$ & $\begin{array}{c}\text { Control } \\
\text { (medium) }\end{array}$ \\
\hline -P, exponential, live culture & 0.36 & $20 \pm 6^{*}$ & $2 \pm 3$ \\
-P, exponential, live culture & 1.6 & $31 \pm 10$ & $21 \pm 10$ \\
+P, exponential, live culture & 3.2 & $25 \pm 8$ & $21 \pm 10$ \\
-P, stationary, lysate & 36 & $19 \pm 8^{*}$ & $6 \pm 6$ \\
Field sample, mixed & 1 & 20 & 0 \\
\hline
\end{tabular}

* Significantly different from the control (student $t$-test, $n=5, p<0.05$ ). 
dominated by Eudiaptomus graciloides. Cells of $P$. aciculiferum (275 cells $\mathrm{ml}^{-1}$ final concentration) were added to each well with $1 \mathrm{ml}$ of filtered lake water and $1 \mathrm{ml}$ of DM medium. As controls, Rhodomonas lacustris cells (final concentration 100,000 cells $\mathrm{ml}^{-1}$ ) were added in a mixture of 1 $\mathrm{ml}$ lake water $+1 \mathrm{ml}$ DM medium. One copepod (manually picked) was added to each well with 12 replicates for each treatment. The wells were incubated in the same conditions as $A$. salina and D. galeata. Cultures of $P$. aciculiferum were also diluted with filtered lake water to give a dilution series of $85,115,170,230,285$, and 340 cells $\mathrm{ml}^{-1}$ (final concentration). Six milliliters of cultures were added to $10-\mathrm{ml}$ wells (Falcon multiwells, six wells). To each well, $1 \mathrm{ml}$ of lake water was added along with one copepod. All treatments were incubated as in the experiments above. Wells were checked after $24 \mathrm{~h}$ for $E$. graciloides viability.

Allelopathy experiment-Two milliliters of P-limited cultures $\left(1,000\right.$ cells $\left.\mathrm{ml}^{-1}\right)$ or cell-free filtrates of $P$. aciculiferum were transferred into 5-ml microwells. Aliquots $(100 \mu \mathrm{l})$ of Rhodomonas lacustris cultures were added to each well (five replicates) at two final cell densities (209 \pm 5 and $1704 \pm 327$ cells $\mathrm{ml}^{-1}$ ), i.e., Peridinium:Rhodomonas ratios of $1: 0.2$ and $1: 2$ respectively. As a control, $R$. lacustris cells (at the two cell densities above) were diluted with $2 \mathrm{ml}$ of DM medium. All wells were incubated under the same conditions as the experiments listed above. Samples were taken after 0, 12, 24, and $48 \mathrm{~h}$, and were preserved with Lugol's solution for enumeration of $R$. lacustris cells. Samples (50-300 $\mu$ l) were settled and counted in an inverted microscope at $400 \times$ magnification. Rhodomonas lacustris cells were also scored for blistering, which is indicative of membrane disruption.

\section{Results}

Field sampling-The phytoplankton counts showed that there were no Peridinium aciculiferum cells at the Ekoln site in Lake Mälaren and at most 240 cells $\mathrm{L}^{-1}$ on one occasion (22 February 2000) at the Adelsö site (Table 1). Ice conditions at Adelsö were poor, and after 10 March 2000 this site had open water. Lake Erken, on the contrary, had a maximum of 40,640 cells $\mathrm{L}^{-1}$ on 3 March 2000. The $>20-\mu \mathrm{m}$ fraction in Lake Erken also contained several diatom species. As the winter of 2000 was unusually mild, ice conditions were variable and thin. The ice did not form until January on Lake Erken, but was $40 \mathrm{~cm}$ thick by mid-March.

Hemolytic activity-Hemolytic activity (HA) was detected both in concentrates of field samples (Lake Erken) containing $P$. aciculiferum and in laboratory cultures (Table 3). In Lake Erken samples, HA was higher on 14 March 2000 (2.9 SnEq cell $^{-1}$ ) than on 3 March 2000 (below detection), corresponding to a $P$. aciculiferum cell abundance of 40,640 and 16,880 cells $\mathrm{L}^{-1}$, respectively. Hemolytic activity was not measured in the other field samples (e.g., Lake Mälaren), since P. aciculiferum concentrations were lower than 17,000 cells $\mathrm{L}^{-1}$.

In $P$. aciculiferum cultures, HA was demonstrated both with horse and fish blood, with values falling within the same range. Hemolytic activity of $P$. aciculiferum was 1.1$1.6 \mathrm{SnEq} \mathrm{cell}{ }^{-1}$ (horse blood) in cultures collected during stationary phase, while HA of exponentially growing cells was below detection (Table 3). Highest HA was measured in cells grown under P-limiting conditions, amounting to $1.61 \pm 0.32 \mathrm{SnEq} \mathrm{cell}^{-1}$ for horse blood and $2.38 \pm 0.19$ SnEq cell ${ }^{-1}$ for fish blood (Table 3).

Toxicity of $\mathrm{P}$. aciculiferum toward zooplankton-Cell lysate of $P$. aciculiferum from cultures and field samples had a lethal effect on Artemia salina. Phosphorus-limited exponential phase cultures (360 cells $\mathrm{ml}^{-1}$ ) killed $20 \%$ of the $A$. salina, which was significantly higher (Student $t$-test, $p<$ $0.05)$ than in the control after $24 \mathrm{~h}$ (Table 4). On the other hand, at the higher concentration $\left(1,600\right.$ cells $\left.\mathrm{ml}^{-1}\right)$, mortality did not differ significantly from the control $(p>0.05)$. However, the low power of the latter test suggests that negative effects should be interpreted cautiously. Phosphorus replete cultures $\left(3,200\right.$ cells $\left.\mathrm{ml}^{-1}\right)$ were not toxic to $A$. salina $(p>0.05)$. In contrast, stationary phase P-limited $P$. aciculiferum lysate $\left(36,000\right.$ cells $\left.\mathrm{ml}^{-1}\right)$ had a significant negative effect (Student $t$-test, $p<0.05$ ) on A. salina survival (Table 4). In addition, cells lysate from Lake Erken samples appeared to have a toxic effect as they caused $20 \%$ mortality of A. salina, while no mortality was observed in controls (Table 4). Repeated ANOVA of two treatments (P-deplete, 1,600 and 36,000 cells $\mathrm{ml}^{-1}$ ) showed that time did not have a significant effect on survival of $A$. salina, which is why the $48 \mathrm{~h}$ data are not shown in Table 4.

Daphnia galeata and E. graciloides were not adversely affected by live $P$. aciculiferum cells. The mortality of $D$. galeata over 24 and $48 \mathrm{~h}$ did not differ between the treatments with $P$. aciculiferum and the controls. No copepods died in any of the treatments; instead they seemed to feed on the dinoflagellate cells, which was confirmed by cell findings in fecal pellets. Observation of the fecal pellets by microscopy revealed that most of the $P$. aciculiferum cells were intact (light microscopy) and bright red (epifluorescence, blue light).

Allelopathic effect-The results show that cells and cell-free filtrates of $P$. aciculiferum have an allelopathic effect on Rhodomonas lacustris. At a high ratio (1:0.2) of Peridinium:Rhodomonas, $R$. lacustris cells grew significantly poorer in $P$. aciculiferum treatments (live cells and filtrate) than in controls (Repeated ANOVA, Scheffe's Test, $p<0.0001$, both treatments) (Fig. 2a). In the $P$. aciculiferum treatments, the number of $R$. lacustris decreased sharply after $24 \mathrm{~h}$. After $48 \mathrm{~h}$, the populations of $R$. lacustris cells exposed to $P$. aciculiferum were below the initial cell concentration $\left(<209\right.$ cells $\left.\mathrm{ml}^{-1}\right)$, while they reached 600 cells $\mathrm{ml}^{-1}$ in the controls.

At low ratios $(1: 2)$ of Peridinium:Rhodomonas, the growth of $R$. lacustris was only slightly affected by $P$. aciculiferum cells or cell-free filtrates compared to the control. However, this difference was not significant (Repeated ANOVA, Scheffe's Test, $p=0.06$ and $p=0.09$ ), indicating a lack of allelopathic effect of $P$. aciculiferum under these conditions (Fig. 2b).

Microscopic counts revealed that the allelopathic substances produced by $P$. aciculiferum caused the formation of blisters or bubbles on the cells of $R$. lacustris. Eventually these appeared to burst, resulting in cell death. In the $1: 0.2$ 

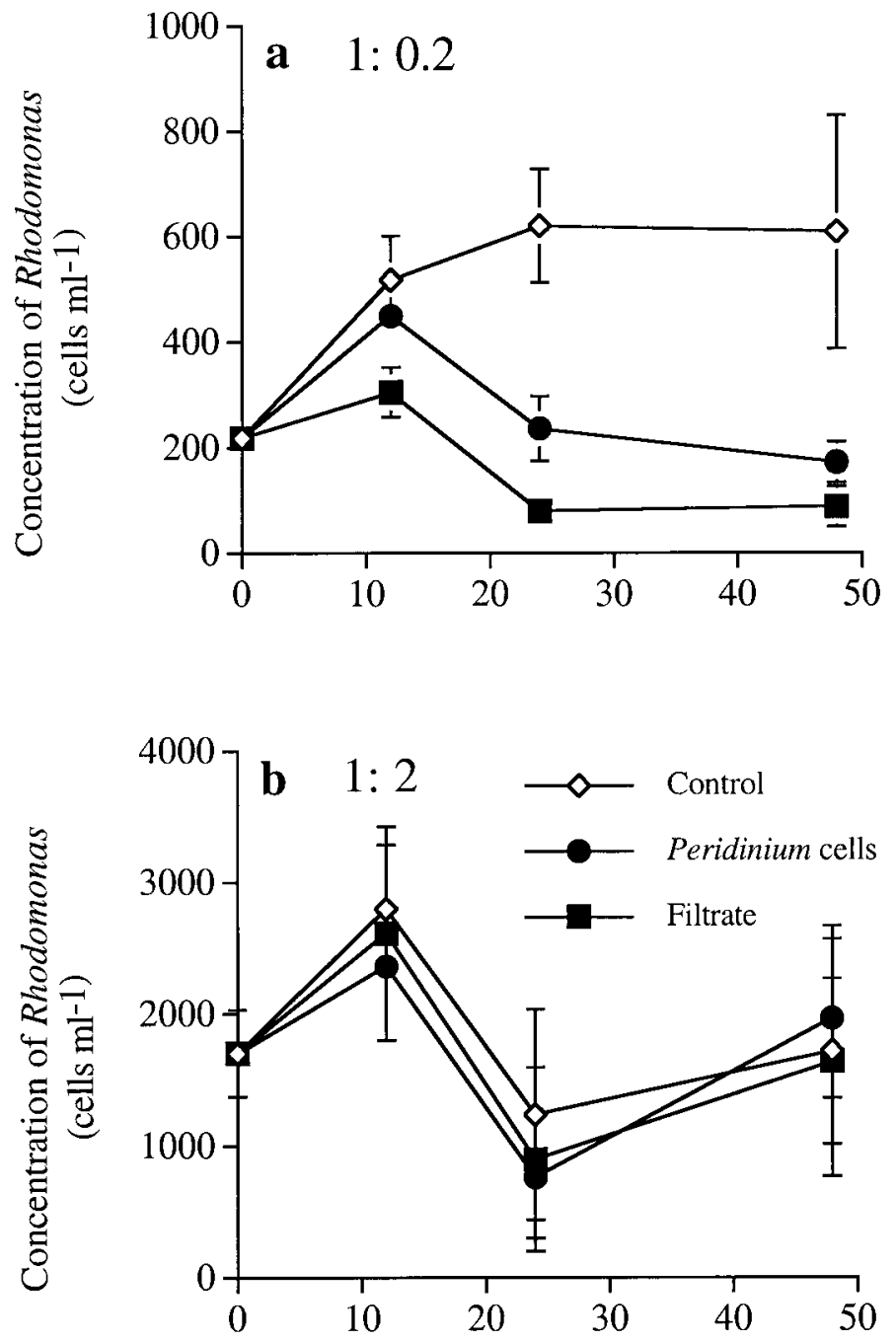

Time (h)

Fig. 2. Allelopathic effect of Peridinium aciculiferum toward Rhodomonas lacustris at two different treatment ratios: 1:0.2 and $1: 2$ of Peridinium: Rhodomonas. Vertical error bars show standard deviation $(n=4)$. (a) 1:0.2 Peridinium: Rhodomonas. Growth response of $R$. lacustris ( $209 \pm 5$ cells $\mathrm{ml}^{-1}$ ) exposed to cultures and cell-free filtrates of $P$. aciculiferum $\left(1,000\right.$ cells $\left.\mathrm{ml}^{-1}\right)$ grown under low phosphorus concentrations. As controls, R. lacustris cultures were diluted with sterile filtered medium.(b) $1: 2$ Peridinium:Rhodomonas. Growth response of $R$. lacustris $\left(1,704 \pm 327\right.$ cells $\left.\mathrm{ml}^{-1}\right)$ exposed to cultures and cell-free filtrates of $P$. aciculiferum $(1,000$ cells $\mathrm{ml}^{-1}$ ) grown under low phosphorus concentrations.

Peridinium: Rhodomonas treatment, blistered cells of $R$. lacustris were first recorded after $24 \mathrm{~h}$. Up to $50 \%$ of the cells were blistered in the filtrate treatment (Fig. 3). No blistered cells were observed in the control and were thus not reported in the figure. The percentage of blistered cells had decreased after $48 \mathrm{~h}$ in both the cultures and filtrate treatments, reflecting the death of blistered cells, which increases the proportional importance of healthy cells. In the $1: 2$ Peridinium: Rhodomonas treatment, blistered cells were also observed, even though no allelopathic effect was detected in the total

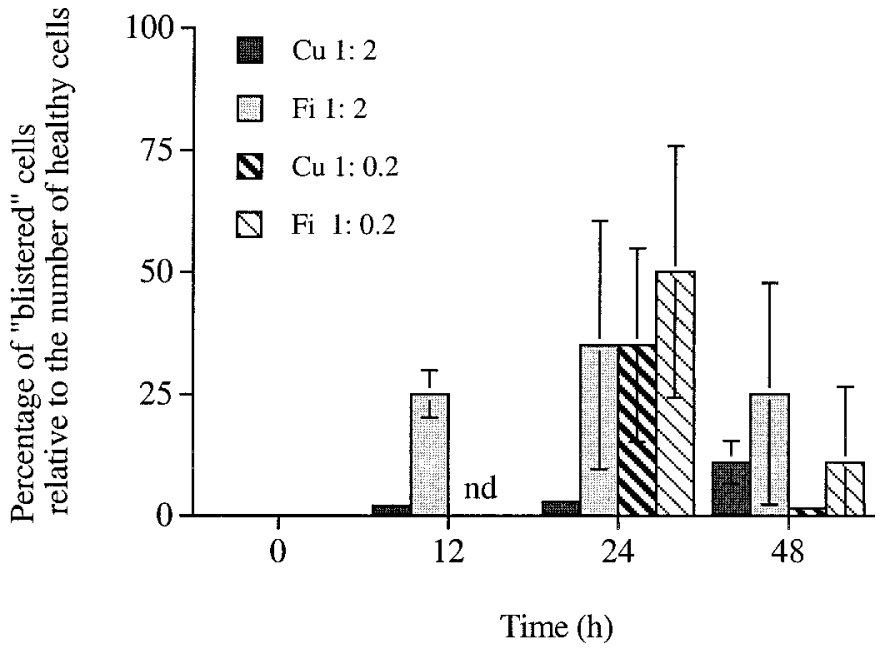

Fig. 3. Percentage of blistered Rhodomonas lacustris cells exposed to cultures $(\mathrm{Cu})$ and cell-free filtrates $(\mathrm{Fi})$ of Peridinium aciculiferum grown under low phosphorus concentration. Treatments with ratios of $1: 0.2$ and $1: 2$ between Peridinium:Rhodomonas are shown. Vertical error bars show standard deviation $(n=4)$. Control values are not shown on the graph since no blistered cells were observed. Note that low percentages in $\mathrm{Cu} 1: 0.2$ are due to the fact that most cells have already lysed and died.

cell counts. Blistered cells were observed only after $12 \mathrm{~h}$ of exposure to $P$. aciculiferum cells and cell-free filtrates, reaching $25 \%$ in the treatment with the $P$. aciculiferum cellfree filtrates (Fig. 3). In the filtrate treatment, the number of blistered R. lacustris cells remained at about $25 \%$ of the total number of cells throughout the $48 \mathrm{~h}$ of the experimental run. Remains of lysed cells were present both in the culture and filtrate treatments at both Peridinium: Rhodomonas ratios.

\section{Discussion}

In this set of experiments, we show that the freshwater species Peridinium aciculiferum produces a toxin or an array of toxins lethal to other planktonic organisms, particularly other phytoplankton (allelopathy). To our knowledge, this is the first winter species to be reported as allelopathic and only the second species of freshwater dinoflagellates identified as a toxin producer.

Through the use of a traditional toxicity test (hemolytic activity) we could establish that a toxin(s) is produced by $P$. aciculiferum. Phosphorus (P) limited cells harvested during stationary phase had a higher hemolytic activity than cells grown in P-replete medium, indicating that the toxin production in $P$. aciculiferum may be influenced by the nutrient status of the medium in which they are growing and/or the cellular P quotas. Nutrient limitation is known to enhance toxin content/production in marine dinoflagellates (Anderson et al. 1990), diatoms (Bates et al. 1991), and haptophytes (Johansson and Granéli 1999). Whether P limitation (low internal $\mathrm{P}$ quota) or growth limitation per se influences the toxicity of $P$. aciculiferum is not known. The crucial question then becomes whether $P$. aciculiferum is likely to experience P limitation in the field. Although nutrient levels 
are generally high under ice, especially at the beginning of winter, $P$. aciculiferum can outstrip the pelagic zone of orthophosphate before ice-out (Pettersson 1985). Consequently, it is possible that a situation of nutrient limitation occurs when the cell density of $P$. aciculiferum becomes high. Regardless, field samples dominated by $P$. aciculiferum showed hemolytic activity, thereby supporting the assumption that toxin production occurs in the field.

Through our experiments we attempted to gain insight into the potential adaptive function of the dinoflagellate toxin. Toxin production as a predator defense mechanism was tested by exposing zooplankton to live cells and cell-free filtrates of $P$. aciculiferum. A moderate toxic effect of $P$. aciculiferum on Artemia salina (standard bioassay used for toxicity tests in marine organisms) provided further support for toxin production. This result, however, cannot be interpreted as the toxin being directed toward potential predators. This is because A. salina is a brackish species that cannot naturally cooccur with $P$. aciculiferum. The other toxicity tests showed that $P$. aciculiferum did not have an acute toxic effect on the naturally cooccurring predatory species Daphnia galeata (Cladocera) and Eudiaptomus graciloides (Copepoda). The winter period in lakes is usually a time of remarkably low densities of dinoflagellate predators, and it appears that toxicity in $P$. aciculiferum did not evolve as a defense against predators. However, it should be noted that intact cells of $P$. aciculiferum were observed in the fecal pellets of E. graciloides, suggesting that most of the ingested cells were not digested. This observation leads us to speculate on the potential sublethal toxic effect of $P$. aciculiferum toward grazers. If the dinoflagellate cells are not digested, are they not digested because they are toxic, and can this lead to starvation in copepods? Another issue is that since the zooplankton used in this experiment cooccur with $P$. aciculiferum, it is possible that these strains have coevolved with the dinoflagellate and are immune to its toxins. Similar tests with zooplankton from lakes without $P$. aciculiferum may render different results. These and other issues must be addressed in further experiments.

Although predator defense does not appear to be an adaptive function of the $P$. aciculiferum toxin, our results support the hypothesis that $P$. aciculiferum produces toxins to outcompete other phytoplankton. Peridinium aciculiferum had an algicidal effect on its competitor Rhodomonas lacustris. This effect is referred to as allelopathy, defined as "the direct effect of competitors through the release of chemicals that inhibit other species" (Lampert and Sommer 1997). In aquatic systems, freshwater cyanobacteria are known to produce allelopathic substances that can inhibit or kill other algae (Gross et al. 1991; Bagchi and Marwah 1994; Von Elert and Jüttner 1996), as are marine diatoms (Sharp et al. 1979), and haptophytes (Johansson 2000). Among dinoflagellates, both marine (Arzul et al. 1999; Uchida et al. 1999) and freshwater (e.g., Peridinium bipes in Wu et al. 1998) species have shown a strong allelopathic effect on cooccurring phytoplankton species.

Peridinium aciculiferum grown under P-limited conditions produces allelopathic substances. These substances are synthesized inside the cells and released in the surrounding medium either as a secondary metabolite or specifically when the $P$. aciculiferum cells encounter $R$. lacustris. At high ratios of Peridinium:Rhodomonas $(1: 0.2)$ the $R$. lacustris population crashed, while at low ratios $(1: 2)$ the dinoflagellate did not significantly affect the growth of $R$. lacustris. These results are in agreement with Johansson (2000), who showed that the haptophyte Prymnesium parvum had an inhibitory effect on Rhodomonas baltica growth only at high ratios of Prymnesium: Rhodomonas (10:1). The explanation for the observed effect may be that at higher densities of $R$. lacustris the amount of Peridinium toxin per Rhodomonas cell is smaller than at low densities, given that the $P$. aciculiferum density is kept the same. Consequently, higher $R$. lacustris biomass could dilute the toxicity.

The allelopathic compounds produced by $P$. aciculiferum appear to damage the cell membrane in R. lacustris as indicated by the presence of blistered and lysed $R$. lacustris cells in Peridinium culture and filtrate treatments. These results are in accordance with the cell-membrane disrupting action of the water-soluble algicidal extract of $P$. bipes (Wu et al. 1998). It should also be noted that the lysing of $R$. lacustris is homologous to the lysing of blood cells, as quantified in the hemolytic activity tests. Nevertheless, we cannot be sure that the toxin causing Artemia mortality or hemolytic activity is the same compound causing the allelopathic response in $R$. lacustris. The filtrate apparently caused more blistering than the intact cells, possibly due to the release of more allelopathic substances during the filtration process. Although no allelopathic effect was detected at the low ratio $(1: 2)$ of Peridinium:Rhodomonas, blistered cells were observed in these samples as well, indicating a sublethal effect of the toxin. The apparent low proportion of blistered cells after $48 \mathrm{~h}$ in all treatments is explained by the fact that at this time point, most blistered cells had lysed and disappeared, leaving behind only the healthy cells. As a result, the proportion of healthy cells increased, although the cell number decreased. Since the same effect was seen in both cultures and filtrate treatments, the lack of increase in blistered cells cannot be attributed to attenuation of toxicity due to degradation of the allelopathic compound.

The production of allelopathic substances by $P$. aciculiferum may be an adaptive strategy to outcompete other phytoplankton, allowing it to dominate the under-ice phytoplankton community. Peridinium aciculiferum cooccurs under ice along with other flagellates such as Rhodomonas and Cryptomonas spp. (Cryptophyceae). These species are typically found in low numbers throughout the winter season, making up at most $1 / 10$ of the dinoflagellate biomass at the peak of the $P$. aciculiferum bloom in April in Lake Erken (Nauwerck 1963). As a large dinoflagellate, P. aciculiferum $(35-40 \mu \mathrm{m})$ is at a disadvantage when competing with other small algae for nutrients, especially other flagellated ones (10 $\mu \mathrm{m}$ or less), which can migrate vertically just like the dinoflagellates. However, by excreting an algicidal compound, $P$. aciculiferum could prevent other phytoplankton from growing to high biomasses, thereby reducing competition for nutrients. In fact, not only is it possible to reduce the nutrient competition through allelopathy, but by causing other phytoplankton to burst and release organically bound nutrients, $P$. aciculiferum may be able to use these organic nutrients as well. 
To conclude, our results show that the large winter dinoflagellate $P$. aciculiferum can produce a toxic substance(s), and that this substance could allow $P$. aciculiferum to outcompete small flagellated phytoplankton that are better at nutrient uptake and have lower nutrient requirements. Thus, the common assumption that the winter confers a period of high nutrient levels, low competition, and low predation may not be an accurate depiction of the under-ice environment. In fact, several species are able to tolerate low temperature and light levels, and nutrients may be outstripped toward the end of the ice-covered period prior to spring turnover, when nutrients are redistributed in the water. Thus, the ability to excrete algicidal substances may provide dinoflagellates with sufficient nutrients to grow, and thereby dominate the phytoplankton community.

\section{References}

ADACHI, R. 1965. Studies on a dinoflagellate Peridinium polonicum Woloszynska. I. The structure of skeleton. J. Fac. Fish., Prefectural University of Mie 6: 318-326.

Ahlgren, G., I.-B. Gustafsson, And M. Boberg. 1992. Fatty acid content and chemical composition of freshwater microalgae. J. Phycol. 28: 37-50.

Anderson, D. M., D. M. Kulis, J. J. Sullivan, S. Hall, and C. LEE. 1990. Dynamics and physiology of saxitoxin production by the dinoflagellates Alexandrium spp. Mar. Biol. 104: 511524.

Arzul, G., M. Seguel, L. Guzman, and E. Erard-Le-Denn. 1999. Comparison of allelopathic properties in three toxic $\mathrm{Al}$ exandrium species. J. Exp. Mar. Biol. Ecol. 232: 285-295.

BAGCHI, S. N., AND J. B. MARWAH. 1994. Production of an algicide from cyanobacterium Fischerella species which inhibits photosynthetic electron transport. Microbios 79: 187-193.

Bates, S. S., A. S. W. De Freitas, J. E. Milley, R. Pocklington, M. A. Quilliam, J. C. Smith, AND J. Worms. 1991. Controls on domoic acid production by the diatom Nitzschia pungens $\mathrm{f}$. mulitiseries in cultures: Nutrients and irradiance. Can. J. Fish. Aquat. Sci. 48: 1136-1144.

Beakes, G., H. M. Canter, and G. H. M. Jaworski. 1988. Zoospore ultrastructure of Zygorhizidium affluens Canter and Z. planktonicum Canter, two chytrids parasitizing the diatom Asterionella formosa Hassall. Can. J. Bot. 66: 1054-1067.

Burkholder, J. M., H. B. Glasgow JR., AND C. W. HobBs. 1995. Fish kills linked to a toxic ambush-predator dinoflagellate: Distribution and environmental conditions. Mar. Ecol. Prog. Ser. 124: 43-61.

Gross, E. M., C. P. WolK, AND F. JÜTTner. 1991. Fischerellin, a new allelochemical from the freshwater cyanobacterium Fischerella musicola. J. Phycol. 27: 686-692.

Hashimoto, Y., T. Okaichi, L. D. Dang, and T. Noguchi. 1968. Glenodinine, an ichtyotoxic substance produced by a dinoflagellate, Peridinium polonicum. Bull. Jpn. Soc. Sci. Fish. 528533.

HJORT, J. 1914. Fluctuations in the reat fisheries of northern Europe viewed in light of biological research. Rapport des Proces Verbaux du Conseil Permanent International d'Exploration de la Mer 20: 1-228.

JoHANSSON, N. 2000. Ecological implications of the production of toxic substances by fish killing phytoplankton grown under variable N:P ratios. Ph.D. thesis, Univ. Lund, Sweden.

, AND E. GRANÉLI. 1999. Influence of different nutrient con- ditions on cell density, chemical composition and toxicity of Prymnesium pavum (Haptophyta) in semi-continuous cultures. J. Exp. Mar. Biol. Ecol. 239: 243-258.

Jurgens, K. 1953. The red tide of Lake Austin, Texas. Game and Fish 2: 8.

LAMPERT, W., AND U. SOMMER. 1997. Limnoecology: The ecology of lakes and streams. Oxford Univ. Press.

LASKER, H. 1971. Field criteria for survival of anchovy larvae: The relation between inshore chlorophyll maximum layers and successful first feeding. Fish. Bull. 73: 453-462.

LiNDSTRÖM, K. 1991. Nutrient requirements of the dinoflagellate Peridinium gatunense. J. Phycol. 27: 207-219.

Mills, K. H., S. M. ChalanchuK, and D. J. Allan. 1995. The fish kills in Lake 302S, an experimentally acidified lake, p. 261. In J. Wisniewski, P. Grennfelt, H. Rodhe, and E. Thörnelöf [eds.], Acid Reign '95 Göteborg, Sweden. Kluwer.

NAUWERCK, A. 1963. Die Beziehungen zwischen Zooplankton und Phytoplankton im See Erken. Symb. Bot. Upsal. 17: 1-163.

Nyberg, P., H. Auvinen, E. Bergstrand, E. Degerman, O. EnDERLEIN, AND A. FJÄLLING. 1998. Siklöjeundersökningar i Mälaren 1991-97. PM 19980817. Fiskeriverket.

Pettersson, K. 1985. The availability of phosphorus and the species composition of the spring phytoplankton in Lake Erken. Int. Rev. Gesamten Hydrobiol. 70: 527-546.

Popovsky, J., And L. A. Pfiester. 1990. Dinophyceae, p. 209211. In H. Ettl, J. Gerloff, H. Heynig, and D. Mollenauer [eds.], Süßwasserflora von Mitteleuropa. 6. Fisher.

RENGEFORS, K. 1998. Seasonal succession of dinoflagellates coupled to the benthic cyst dynamics in Lake Erken, Sweden. Arch. Hydrobiol. Spec. Issue Adv. Limnol. 51: 123-141.

Sharp, H. J., P. A. Underhill, AND D. J. Hughes. 1979. Interactions (allelopathy) between marine diatoms: Thalassiosira pseudonana and Phaeodactylum tricornutum. J. Phycol. 15: 353-362.

Spataru, P. 1976. The feeding habits of Tilapia galilaea (Artedi) in Lake Kinneret (Israel). Aquaculture 9: 47-59.

SteIdiNGER, K. 1983. A re-evaluation of toxic dinoflagellate biology and ecology, p. 147-188. In F. E. Round and D. J. Chapman [eds.], Progress in Phycological Research 2. Elsevier.

Turner, J. T., And P. A. Tester. 1997. Toxic marine phytoplankton, zooplankton grazers, and pelagic food webs. Limnol. Oceanogr. 42: 1203-1214.

, $\longrightarrow$, AND P. J. HANSEN. 1998. Interactions between toxic marine phytoplankton and metazoan and protistan grazers, p. 453-474. In D. M. Anderson, A. D. Cembella, and G. M. Hallegraeff [eds.], Physiological ecology of harmful algal blooms. Springer.

Uchida T., S. Toda, Y. Matsuyama, M. Yamaguchi, Y. Kotani, AND T. HonJo. 1999. Interactions between the red tide dinoflagellates Heterocapsa circularisquama and Gymnodinium mikimotoi in laboratory culture. J. Exp. Mar. Biol. Ecol. 241: 285299.

Vanhaecke, P., G. Persoone, C. Claus, And P. Sorgeloos. 1981. Proposal for a short-term toxicity test with Artemia nauplii. Ecotoxicol. Environ. Saf. 5: 382-387.

Von EleRT, E., AND F. JÜTTNER. 1996. Factors influencing the allelopathic activity of the planktonic cyanobacterium Trichormus doliolum. Phycologia 35: 68-73.

Wu, J.-T., L.-L. Kuo-HuAnG, AND J. LeE. 1998. Algicidal effect of Peridinium bipes on Microcystis aeruginosa. Curr. Microbiol. 37: 257-261.

Received: 11 December 2000 Amended: 23 July 2001 Accepted: 27 August 2001 